\title{
Pengaruh Pemberian Reward dengan Model Tabungan Kepingan Terhadap Kepatuhan Anak Usia Dini
}

\section{The Effect of Rewarding with the Chip Savings Model on Early Childhood Compliance}

\author{
Muhammad Erwan Syah \\ Program Studi Psikologi, Universitas Jenderal Achmad Yani, Indonesia \\ Diterima : 17 April 2020; Disetujui : 18 April 2020; Dipublish : 30 April 2020 \\ *Corresponding author: E-mail: muhammaderwansyah@yahoo.com
}

\begin{abstract}
Abstrak
Penelitian ini untuk mengetahui pengaruh pemberian reward dengan model tabungan kepingan terhadap kepatuhan anak usia dini. Subjek terdiri empat siswa. Analisis data menggunakan statistika non parametrik uji Friedman dan dilakukan analisis tambahan dengan Uji peringkat bertanda Wilcoxon. Alat ukur menggunakan behavioral check list kepatuhan anak. Metode penelitian menggunakan eksperimental small $N$ design dengan format ABA. Hasil penelitian ini menunjukkan bahwa uji Friedman didapat $\left(X^{2}\right)=6,500$ dengan $p=0,039(p<0,05)$. Uji peringkat bertanda Wilcoxon menunjukkan ada perbedaan kepatuhan yang signifikan antara fase baseline (A1) dengan fase perlakuan (B) nilai $\mathrm{Z}=-1,826$ dengan $\mathrm{p}=0,034, \mathrm{p}<0,05$. Selain itu antara fase baseline (A1) dengan fase baseline (A2) ada perbedaan kepatuhan yang signifikan nilai $\mathrm{Z}=-1,826$ dengan $\mathrm{p}=0,034, \mathrm{p}<0,05$. Tidak ada perbedaan kepatuhan antara fase baseline (A2) dengan fase perlakuan (B) nilai $\mathrm{Z}=-1,461$ dengan $\mathrm{p}=0,072, \mathrm{p}>0,05$. Kesimpulannya ada pengaruh pemberian reward dengan model tabungan kepingan terhadap kepatuhan anak usia dini. Ada peningkatan kepatuhan anak usia dini ketika diberikan reward dengan model tabungan kepingan.
\end{abstract}

Kata Kunci : Kepatuhan Anak Usia Dini; Model Tabungan Kepingan; Reward.

\begin{abstract}
This study is to determine the effect of rewarding with a piece savings model on early childhood compliance. The subject consisted of four students. Data analysis using non-parametric statistics Friedman test and additional analyzes performed with the Wilcoxon signed rank test. Measuring devices use behavioral check lists of child compliance. The research method uses an experimental small $N$ design with $A B A$ format. The results of this study indicate that the Friedman test was obtained $\left(X^{2}\right)=6,500$ with $p=0.039(p<0.05)$. The Wilcoxon signed rank test shows that there is a significant difference in compliance between the baseline phase (A1) and the treatment phase (B) the value of $Z=-1.826$ with $p=0.034, p<0.05$. Besides that, between the baseline (A1) and baseline (A2) phases there was a significant difference in compliance with the value of $Z=-1.826$ with $p=0.034, p<0.05$. There was no difference in compliance between the baseline phase (A2) and the treatment phase (B) the value of $Z=-1,461$ with $p=0.072, p>0.05$. In conclusion, there is an effect of giving rewards with pieces of savings model on early childhood compliance.
\end{abstract}

Keywords: Early Childhood Compliance; Pieces Savings Model; Reward.

\section{Rekomendasi mensitasi :}

Syah, E.M. (2020), Pengaruh Pemberian Rewarddengan Model Tabungan Kepingan Terhadap Kepatuhan Anak Usia Dini. Jurnal Penelitian Pendidikan, Psikologi dan Kesehatan (J-P3K), 1(1): 50-60. 


\section{PENDAHULUAN}

Kepatuhan dan konformitas dipandang sebagai suatu hal yang positif dan merupakan aspek yang ditekankan sebagai bentuk perilaku sosial yang dihargai dalam budaya timur (Minza, 2001). Berdasarkan dari hasil wawancara pada Mei 2019 dapat diperoleh informasi ada anak-anak yang tidak patuh. Hasil wawancara dengan kepala sekolah, TK ABA Pleret Bantul Yogyakarta mempunyai dua kelas dengan total siswa sejumlah 72 yaitu satu kelas TK A dengan jumlah siswa 34 anak dan satu kelas TK B dengan jumlah siswa 38 anak.

Ketidakpatuhan di TK ini ditunjukkan anak menolak jika disuruh mengerjakan sesuatu. Selain itu berdasarkan hasil observasi dikelas terdapat beberapa anak tidak mau mengikuti berbaris. Saat berdo'a anak hanya ikut setengah atau tidak ikut sama sekali. Anak mengerjakan tugas dengan mengobrol, bercanda dan akhirnya tidak selesai dalam mengerjakan tugas. Anak juga tidak mau mencuci tangan sebelum makan bersama. Bentuk ketidakpatuhan kebanyakkan dilakukan oleh siswa TK.

Uraian di atas dapat dilihat bahwa kepatuhan terhadap aturan dan perintah dari orang tua dan guru (figur otoritas) penting namun perlu diingat cara yang digunakan untuk memperoleh kepatuhan harus sesuai. Tanpa disadari orang tua dan guru merupakan faktor eksternal yang dapat mempengaruhi kepatuhan seorang anak, tidak jarang seorang anak disalahkan karena anak tidak mematuhi aturan yang berlaku tanpa mengetahui penyebab yang bersifat eksternal (Minza, 2001).

Berdasarkan hasil wawancara pada Mei 2019 di TK ABA Pleret masih mengunakan metode sederhana dalam pemberian reward dengan memberikan gambar bintang dan angka pada buku atau catatan anak. Selain itu para guru memberikan acungan jempol sambil berkata "anak pintar", "anak baik", "bagus". Berdasarkan hasil wawancara pada kedua TK ABA Pleret dan Suren belum menggunakan metode pemberian reward dengan model tabungan kepingan.

Soekadji (1983) menyatakan bahwa tabungan keping adalah suatu program pemberian satu kepingan (atau satu tanda, satu isyarat) sesegera mungkin setiap kali setelah perilaku sasaran muncul. Kepingan-kepingan ini nantinya dapat ditukar dengan benda atau aktivitas pengukuhan yang diinginkan subjek. Pengukuhan ini dapat disebut pengukuhan idaman. Keuntungan penggunaan kepingan atau benda-benda isyarat ini adalah kepingan ini dapat diberikan seketika setelah perilaku sasaran dilaksanakan, dan dapat diberikan berulang-ulang.

Ketidakpatuhan anak yang terjadi tidak sesuai dengan harapan orang tua dan guru yang menginginkan anak-anaknya untuk selalu mematuhi aturan-aturan dan norma-norma yang berlaku di masyarakat (seperti patuh, sopan dan menghormati orang yang lebih tua). Idealnya seorang anak usia dini dapat mengikuti dan mematuhi aturan dan perintah sederhana dari figur otoritas seperti anak mau mengikuti berbaris. Anak ikut berdo'a. 
Anak dapat mengerjakan tugas. Anak mau mencuci tangan sebelum makan bersama.

Indikator kepatuhan anak dalam penelitian ini ditunjukkan dalam kesesuaian perilaku anak dengan aturan sekolah dan perintah dari guru seperti ikut berbaris rapi masuk dan pulang sekolah, ikut berdoa masuk dan pulang sekolah dari awal sampai akhir, mengembalikan alat bermain ke tempat semula. Cuci tangan sebelum makan, melaksanakan tugas sendiri yang sesuai diberikan guru sampai selesai dan ikut mengucapkan janji pulang sekolah. Indikator kepatuhan anak berasal dari hasil observasi dan aturan sekolah yang berlaku.

Power (Minza, 2001) mengemukakan faktor-faktor yang mempengaruhi kepatuhan pada anak yaitu (a) keadaan anak. Meskipun temperamen, mood dan jenis kelamin anak termasuk variabel yang berpengaruh dalam situasi pendisiplinan, dilihat dari segi perkembangan anak, usia merupakan variabel yang lebih dominan dalam mempengaruhi sejauh mana upaya pendisplinan berpengaruh terhadap perilaku anak; (b) keadaan orang tua. Keadaan orang tua juga berpengaruh terhadap kepatuhan anak.

Menurut Hurlock (1991) reward atau penghargaan dibagi menjadi tiga bagian yaitu (a) penerimaan sosial. Penerimaan sosial dapat berupa pujian kepada anak, pujian diharapkan mempunyai nilai edukatif, tetapi supaya efektif pujian harus digunakan dengan bijaksana; (b) materi. Hadiah berupa benda atau barang diberikan sebagai penghargaan untuk perilaku yang baik,; (c) perilaku yang istimewa. Perilaku yang istimewa pada anak dapat berupa perhatian kepada anak.

Menurut Soekadji (1983) agar penerapan reward efektif maka perlu dipertimbangkan berbagai syarat antara lain (a) menyajikan pengukuh seketika. Prinsip pengukuh seketika lebih efektif karena penyajian pengukuh seketika setelah tindakan atau perilaku berlangsung tanpa adanya penundaan; (b) memilih pengukuh yang tepat. Tidak semua imbalan dapat berupa reward karena sikap orang mempunyai selera berbeda; (c) mengatur kondisi situasional. Agar perilaku yang mendapat reward berulang pada saat atau kondisi yang tepat perlu diatur kondisi situasional pemberian reward.

Syarat penerapan reward efektif selanjutnya adalah; (d) menentukan kuantitas reward. Kuantitas reward adalah banyaknya reward yang akan diberikan setiap kali seseorang berhasil melakukan tingkah laku tertentu; (e) memilih kualitas. Seseorang cenderung menyukai sesuatu yang berkualitas tinggi atau sesuatu yang baru, karena sesuatu yang baru cenderung menghilangkan kebosanan atau kejenuhan sehingga dapat menjadi salah satu reward tetapi dapat pula sebaliknya, kualitas yang tidak sesuai dengan harapan penerima akan menurunnya efektifitas reward;

Penerapan sebagai syarat reward efektif selanjutnya adalah; memberikan sampel reward. Sampel reward yang akan diberikan perlu diperkenalkan dulu agar penerima merasa cocok dan senang dengan 
reward yang diterima; (g) menanggulangi pengaruh saingan. Reward sering tidak efektif karena pengaruh lain yang tidak dikehendaki berpengaruh lebih kuat;

Sebagai syarat penerapan reward efektif yang terakhir adalah (h) mengatur jadwal. Jadwal pemberian reward mempengaruhi lamanya atau kecepatan tingkah laku berlangsung secara garis besar, pemberian reward dapat diatur dalam dua macam yaitu : continuos schedule yaitu reward diberikan terus menerus setiap muncul respon yang dikehendaki. Intermitten atau partial schedule yaitu reward yang diberikan tidak terus menerus setiap kali muncul respon yang diharapkan sehingga hanya sebagian saja yang mendapat reward.

Soekadji (1983) menyatakan bahwa tabungan kepingan atau yang biasa dikenal dengan program token ekonomi. Program token ekonomi merupakan prosedur kombinasi untuk meningkatkan, beberapa perilaku sehingga sangat efektif digunakan. Soekadji (1983) berpendapat bahwa tabungan keping adalah suatu program pemberian satu kepingan atau kartu (atau satu tanda, satu isyarat) sesegera mungkin setiap kali setelah perilaku sasaran muncul.

Selain itu, mengemukakan bahwa kepingan-kepingan ini nantinya dapat ditukar dengan benda atau aktivitas pengukuhan yang diinginkan subjek. Pengukuhan ini dapat disebut pengukuhan idaman. Keuntungan penggunaan kepingan atau benda-benda isyarat ini adalah kepingan ini dapat diberikan seketika setelah perilaku sasaran dilaksanakan, dan dapat diberikan berulang-ulang. Selain itu, program kepingan semacam ini bila dirancang dengan cermat dapat merupakan program yang efektif. Tetapi bila diterapkan secara serampangan akan menimbulkan efek-efek sampingan yang tidak diharapkan (Soekadji, 1983).

Agar efektif kepingan penerapan tabungan perlu memenuhi beberapa aturan dan pertimbangan. Aturanaturan dan pertimbangan tersebut antara lain (Soekadji, 1983) (1) hindari penundaan; (2) berikan kepingan secara konsisten; (3) memperhitungkan kuantitas; (4) persyaratan hendaknya jelas; (5) pilih pengukuh yang macam dan kualitasnya memadai; kelancaran pengadaan pengukuh idaman; (7) pemasaran pengukuh idaman; (8) jodohkan pemberian kepingan dengan pengukuhan sosial positif.

Pemberian reward dengan model tabungan kepingan adalah pemberian pengukuh sementara berupa kepingan atau kartu (atau satu tanda, satu isyarat) segera setelah perilaku yang diinginkan terjadi, setelah terkumpul dalam jumlah tertentu akan ditukarkan dengan reward atau pengukuh yang diharapkan (pengukuh idaman).

Berdasarkan fenomena tersebut, peneliti ingin untuk mengetahui adanya pengaruh pemberian reward dengan model tabungan keping terhadap kepatuhan anak usia dini. Sedangkan hipotesis dalam penelitian ini adalah ada pengaruh pemberian reward dengan model tabungan kepingan terhadap kepatuhan anak usia dini. 


\section{METODE PENELITIAN}

Subjek penelitian ini adalah siswa kelas A TK ABA Pleret Bantul Yogyakarta. Usia subjek penelitian antara empat tahun sampai enam tahun. Variabel bebas dalam penelitian ini adalah pemberian reward dengan model tabungankepingan, sedangkan variabel tergantung yaitu kepatuhan.

Pengumpulan data dalam penelitian ini mengunakan observasi dengan metode behavioral check list. Observasi ini dilakukan terhadap siswa oleh observer dan dicatat dalam lembar observasi yang telah disediakan dan dapat dilihat pada tabel 1 .

Tabel 1. Behavior check list

\begin{tabular}{|c|c|c|}
\hline Aspek & Muncul & $\begin{array}{l}\text { Tidak } \\
\text { muncul }\end{array}$ \\
\hline \multicolumn{3}{|l|}{$\begin{array}{l}\text { Ikut berbaris masuk } \\
\text { sekolah }\end{array}$} \\
\hline \multicolumn{3}{|l|}{ Ikut berdoa masuk sekolah } \\
\hline \multirow{2}{*}{\multicolumn{3}{|c|}{$\begin{array}{l}\text { Mengerjakan tugas sesuai } \\
\text { dengan perintah }\end{array}$}} \\
\hline & & \\
\hline \multicolumn{3}{|l|}{ Mampu mengerjakan tugas } \\
\hline \multicolumn{3}{|l|}{ sendiri } \\
\hline \multirow{2}{*}{\multicolumn{3}{|c|}{$\begin{array}{l}\text { Mengerjakan tugas sampai } \\
\text { selesai }\end{array}$}} \\
\hline & & \\
\hline \multicolumn{3}{|l|}{ Mengembalikan alat } \\
\hline \multicolumn{3}{|l|}{ bermain ke tempat semula } \\
\hline \multicolumn{3}{|l|}{ Cuci tangan sebelum } \\
\hline \multicolumn{3}{|l|}{ makan } \\
\hline \multicolumn{3}{|l|}{ Ikut mengucapkan janji } \\
\hline \multicolumn{3}{|l|}{ pulang sekolah } \\
\hline \multicolumn{3}{|l|}{ Ikut berdoa pulang sekolah } \\
\hline \multicolumn{3}{|l|}{ Ikut berbaris pulang } \\
\hline sekolah & & \\
\hline
\end{tabular}

Rancangan penelitian yang digunakan adalah metode eksperimental small $N$ design, yaitu desain eksperimen untuk mempelajari perilaku pada subjek yang sedikit atau hanya satu subjek. Penelitian ini mengunakan small $N$ design dengan format ABA yaitu melibatkan fase baseline (A1) pada kondisi kontrol awal, selanjutnya menerapkan fase perlakuan (B) kemudian kembali ke kondisi kontrol pada fase baseline (A2) untuk memverifikasi perubahan yang diamati dalam perilaku kepatuhan tanpa perlakuan (Myers, 2002). Berikut tabel rancangan penelitian yang digunakan dan dapat dilihat tabel 2 .

Tabel 2. Rancangan Penelitian

Subjek $\rightarrow A 1 \rightarrow B \rightarrow A 2$

Keterangan :

$\begin{array}{ll}\text { A1 } & \text { fase baseline } \\ \text { B } & \text { : pengukuran kepatuhan } \\ \text { A2 } & \text { : fase baseline kedua tanpa diberi } \\ & \text { perlakuan }\end{array}$

Prosedur penelitian adalah (1) siswa TK ABA Pleret kelas A dipilih sebagai subjek penelitian karena TK tersebut belum di terapkan reward dengan model tabungan kepingan. Selain itu ada beberapa anak tidak mau mengikuti berbaris dengan rapi. Saat berdo'a anak hanya ikut setengah atau tidak ikut sama sekali. Anak mengerjakan tugas dengan mengobrol, bercanda dan akhirnya tidak selesai dalam mengerjakan tugas. Anak juga tidak mau mencuci tangan sebelum makan bersama.

Selanjutnya prosedur penelitian nya adalah (2) Subjek yang diikutsertakan dalam penelitian ini adalah siswa yang skor kepatuhan pada saat baseline (A1) awal dalam kategori rendah dan sedang. Semua aktifitas siswa yang dilihat kepatuhannya adalah berkaitan dengan kegiatan belajar mengajar; (3) iswa yang berhalangan 
hadir (absent) dibatalkan keikutsertaannya sebagai subjek eksperimen.

Prosedur penelitian selanjutnya (4) pengambilan data awal pada fase baseline (A1) melalui observasi pada subjek penelitian dibutuhkan untuk mengetahui siswa yang memiliki kepatuahan yang rendah atau sedang selama di sekolah. Fase baseline (A1) dilakukan selama tiga hari; (5) pada fase perlakuan, peneliti memberikan perlakuan berupa pemberian reward dengan model tabungan keping selama 10 hari dan dilakukan pengukuran kepatuhan pada subjek.

Selanjutnya adalah (6) pada fase perlakuan, subjek penelitian diberikan instruksi oleh guru mereka = "Ibu guru punya koin yaitu warna kuning ada gambar tersenyum. Ibu guru akan memberikan kepingan koin kepada anak-anak. Koin-koin ini akan anak-anak tabung pada celengan yang sudah ada pada meja-meja yang ibu sediakan sesuai dengan kelompok belajarmya, celengan itu masing-masing sudah ada nama kalian.

Kemudian, koin warna kuning ini akan ibu guru berikan apabila anakanak ikut berbaris rapi masuk dan pulang sekolah, ikut berdoa masuk dan pulang sekolah dari awal sampai akhir, mengembalikan alat bermain ke tempat semula dengan rapi, cuci tangan sebelum makan bekal, melaksanakan tugas sendiri yang sesuai diberikan guru sampai selesai, tidak berisik saat mengerjakan tugas selama pelajaran di sekolah dan ikut mengucapkan janji pulang sekolah. Koin warna kuning dalam jumlah 10 dapat ditukarkan dengan sebuah stiker bergambar sesuai dengan keinginan kalian".

Setelah melakukan fase perlakuan, prosedur penelitian selanjutnya adalah (7) peneliti dan obsever mencatat observasi perilaku kepatuhan subjek penelitian selama proses eksperimen; (8) pengambilan data akhir pada fase baseline (A2) tanpa pemberian perlakuan melalui observasi pada subjek penelitian selama tiga hari; (9) waktu penelitian dilakukan pada jam aktif sekolah dari jam setengah delapan sampai jam sepuluh.

Alat-alat yang digunakan dalam penelitian adalah pedoman observasi dan reward. Analisis data yang digunakan untuk menguji hipotesis adalah Uji Friedman. Uji Friedman merupakan suatu teknik statistik non parametrik untuk menguji sampel kecil berhubungan atau amatan ulang yang berfungsi untuk menguji signifikansi perbedaan rerata suatu variabel tergantung antara tiga fase yaitu fase baseline (A1), fase perlakuan, dan fase baseline (A2) sejalan dengan hipotesis penelitian.

Analisis data kepatuhan anak yang digunakan dalam penelitian ini adalah Uji Friedman. Uji Friedman terdapat pada program Statistical Product \& Service Sollution (SPSS) for windows.

\section{HASIL DAN PEMBAHASAN}

Subjek yang digunakan dalam penelitian ini adalah siswa kelas A Taman Kanak-kanak Aisyah Bustanul Athfal Pleret Bantul yang berada di Kelurahan Segoroyoso kecamatan Pleret, Bantul. Subjek penelitian ini 
adalah empat siswa kelas A TK ABA Pleret Bantul. Keempat siswa tersebut berinisial M, Z, F, A dan semuanya berjenis kelamin laki-laki. Semua subjek lahir pada tahun 2015 jadi usia keempat subjek penelitian adalah empat tahun.Penelitian dilaksanakan pada tanggal 8 sampai 29 Juli 2019.

Metode analisis data yang dipakai dalam penelitian ini adalah metode statistik. Analisis data menggunakan bantuan SPSS 15 for windows untuk hasil analisis data dapat dilihat pada lampiran (hasil analisis data). Uji hipotesis dengan menggunakan analisis varian nonparametrik dua arah pengukuran berulang yang dikenal juga dengan teknik uji Friedman.

Uji Friedman tepat digunakan pada sampel kecil dan untuk membandingkan distribusi dua variabel yang berhubungan atau lebih yang diduga secara kuat berasal dari populasi yang memiliki distribusi yang tidak mencerminkan adanya parametrisitas (Budisetyani, 2005). Berdasarkan hasil analisis didapat chi square $\left(\mathrm{X}^{2}\right)=6,500$ dengan asymp. Sig/ asymptotic significance adalah $0,039(\mathrm{p}<0,05)$ maka ada pengaruh pemberian reward dengan model tabungan kepingan yang signifikan terhadap kepatuhan anak usia dini.

Berdasarkan hasil analisis utama diatas yang menyebutkan bahwa pemberian reward dengan model tabungan kepingan berpengaruh signifikan terhadap kepatuhan anak usia dini, kemudian dianalisis lagi untuk mencari perbedaan antar fase penelitian dengan menggunakan uji peringkat bertanda Wilcoxon. Berikut gambar kualitas kepatuhan per subjek penelitian yang terdiri dari fase baseline (1); fase perlakuan (A1); fase baseline (A2).

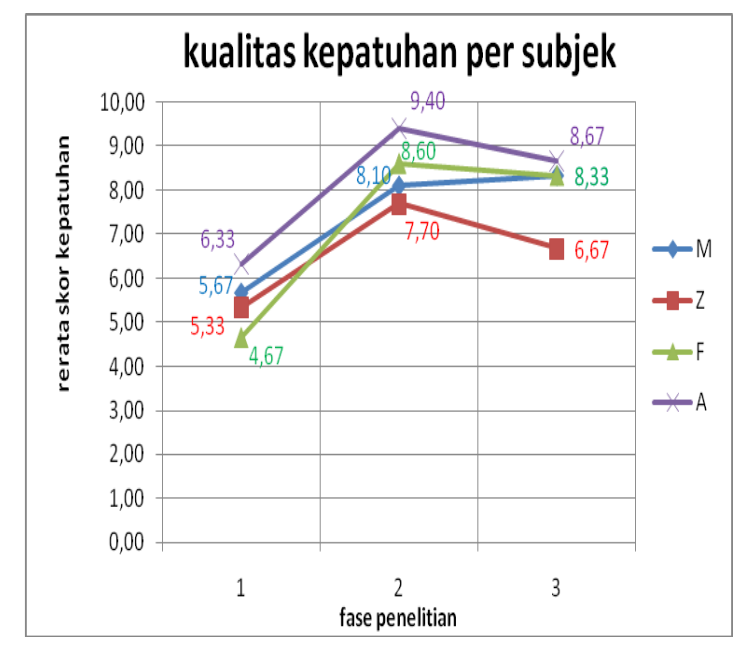

Gambar 1. Kualitas Kepatuhan Per Subjek

Kualitas kepatuhan pada subjek M mempunyai kualitas kepatuhan termasuk kategori sedang dengan rerata skor 5,67 data baseline (A1) pada kondisi kontrol awal, kemudian subjek penelitian diberikan perlakuan (B) dengan pemberian reward metode tabungan kepingan. Pemberian perlakuan itu menyebabkan peningkatan kualitas kepatuhan rerata skor sebesar 2,43 sehingga mencapai rerata skor 8,10 yang masuk dalam kategori tinggi.

Kemudian kembali ke kondisi pada fase baseline (A2) untuk memverifikasi perubahan yang diamati dalam perilaku kepatuhan tanpa perlakuan. Kondisi itu menyebabkan peningkatan rerata skor kepatuhan sebesar 0,23 akan tetapi subjek penelitian masih mempunyai skor kepatuhan adalah 8,33 termasuk dalam kualitas kepatuhan kategori tinggi. 
Subjek Z mempunyai kualitas kepatuhan termasuk kategori sedang dengan rerata skor 5,33 data baseline (A1) pada kondisi kontrol awal, kemudian subjek penelitian diberikan perlakuan (B). Pemberian perlakuan itu menyebabkan peningkatan kualitas kepatuhan rerata skor sebesar 2,37 sehingga mencapai rerata skor 7,70 yang masuk dalam kategori tinggi, kemudian kembali ke fase baseline (A2). Kondisi itu menyebabkan penurunan rerata skor kepatuhan sebesar 1,03 akan tetapi subjek penelitian masih mempunyai skor kepatuhan adalah 6,67 termasuk dalam kualitas kepatuhan kategori tinggi.

Subjek F mempunyai kualitas kepatuhan termasuk kategori sedang dengan rerata skor 4,67 data baseline (A1) pada kondisi kontrol awal, kemudian subjek penelitian diberikan perlakuan (B) dengan pemberian reward metode tabungan kepingan. Pemberian perlakuan itu menyebabkan peningkatan kualitas kepatuhan rerata skor sebesar 3,93 sehingga mencapai rerata skor 8,60 yang masuk dalam kategori tinggi.

Kemudian kembali ke kondisi pada fase baseline (A2) untuk memverifikasi perubahan yang diamati dalam perilaku kepatuhan tanpa perlakuan. Kondisi itu menyebabkan peningkatan rerata skor kepatuhan sebesar 0,27 akan tetapi subjek penelitian masih mempunyai skor kepatuhan adalah 8,33 termasuk dalam kualitas kepatuhan kategori tinggi.

Subjek A mempunyai kualitas kepatuhan termasuk kategori sedang dengan rerata skor 6,33 data baseline
(A1) pada kondisi kontrol awal, kemudian subjek penelitian diberikan perlakuan (B). Pemberian perlakuan itu menyebabkan peningkatan kualitas kepatuhan rerata skor sehingga mencapai rerata skor 9,40 kenaikan skor mencapai 3,07 yang masuk dalam kategori tinggi, kemudian kembali ke fase baseline (A2). Kondisi itu menyebabkan penurunan rerata skor kepatuhan sebesar 0,73 akan tetapi subjek penelitian masih mempunyai skor kepatuhan adalah 8,67 termasuk dalam kualitas kepatuhan kategori tinggi.

Berdasarkan analisis data bahwa ada pengaruh pemberian reward dengan model tabungan kepingan yang signifikan terhadap kepatuhan anak usia dini $\left(X^{2}=6,500, p<0,05\right)$ sehingga hipotesis diterima. Hal ini berarti pemberian reward dengan model tabungan kepingan berpengaruh terhadap kepatuhan subjek penelitian. Hasil penelitian membuktikan bahwa penghargaan, pembiasaan yang dilakukan oleh figur otoritas dengan anak sebenarnya merupakan kunci dari keberhasilan mendapat kepatuhan dari anak.

Hasil observasi mendukung bahwa ada pengaruh pemberian reward dengan model tabungan kepingan terhadap kepatuhan anak terbukti pada saat diberi perlakuan menunjukkan peningkatan tingkat kepatuhan pada subjek penelitian. Hasil observasi selama pelaksanaan penelitian juga mendukung prinsip penguat atau pemberian reward (hadiah) adalah sebagai motivasi pada anak agar mematuhi perintah orang tua (figure 
otoritas) dan aturan-aturan yang berlaku.

Hal ini diperkuat oleh law of effect yakni hukum yang menyatakan bahwa kekuatan hubungan dipengaruhi oleh akibat-akibat dari respon. Thordike (Nasrullah dan Nashori, 2004) menyatakan bahwa akibat yang menyenangkan sajalah yang bisa menguatkan hubungan tersebut, sedangkan akibat yang tidak menyenangkan tidak menguatkan.

Berdasarkan analisis uji peringkat bertanda Wilcoxon bahwa ada perbedaan kepatuhan anak usia dini yang signifikan antara sebelum diberi perlakuan dengan pemberian reward model tabungan kepingan dan ketika diberi dengan perlakuan pemberian reward dengan model tabungan kepingan $(\mathrm{z}=-1,826 ; \mathrm{p}=0,034 ; \mathrm{p}<$ $0,05)$ dengan nilai mean (A1) < nilai mean (B) sehingga hipotesis diterima. Hal ini berarti ada perbedaan tingkat kepatuhan.

Kepatuhan anak usia dini sebelum diberi perlakuan dengan pemberian reward model tabungan kepingan lebih rendah daripada ketika diberi perlakuan dengan pemberian reward dengan model tabungan kepingan. Selain itu, ada perbedaan kepatuhan anak usia dini yang signifikan antara sebelum dan sesudah diberi perlakuan dengan pemberian reward model tabungan $\operatorname{kepingan}(z=-1,826 ; p=0,034 ; p<0,05)$ dengan nilai mean $(\mathrm{A} 2)>$ nilai mean (A1) sehingga hipotesis diterima.

Hal ini berarti ada perbedaan tingkat kepatuhan. Kepatuhan anak usia dini sebelum diberi perlakuan dengan pemberian reward model tabungan kepingan lebih rendah daripada sesudah diberi perlakuan dengan pemberian reward dengan model tabungan kepingan. Semua subjek dalam penelitian ini mengalami peningkatan kepatuhan.

Selain pembiasaan dengan cara pemberian reward dengan model tabungan kepingan, subjek penelitian pun diberikan arahan, nasehat dan pengertian mengenai manfaat, tujuan, makna atau arti penting dari perilaku kepatuhan yang diharapkan. Subjek penelitian tidak terlalu antusias terhadap hadiah yang diberikan sehingga nilai-nilai kepatuhan akan tertanamkan, ketika saat tidak diberikan reward perilaku kepatuhan akan cenderung menetap dan tidak hilang.

Pemberian reward dengan model tabungan kepingan memiliki pengaruh signifikan terhadap kepatuhan anak usia dini dengan analisis uji Friedman $\left(\mathrm{x}^{2}=\right.$ 6,500; $\mathrm{p}<0,05$ ) sehingga hipotesis diterima. Dapat dikatakan bahwa ada perbedaan kepatuhan anak usia dini antara sebelum (A1) diberi perlakuan dengan pemberian reward model tabungan kepingan dan ketika diberi dengan perlakuan (B) pemberian reward dengan model tabungan kepingan.

Selain itu, ada perbedaan kepatuhan anak usia dini antara sebelum (A1) dan sesudah (A2) diberi perlakuan dengan pemberian reward model tabungan kepingan. Tetapi tidak ada perbedaan kepatuhan anak usia dini antara ketika diberi perlakuan (B) dengan pemberian reward model tabungan kepingan dan sesudah diberi dengan perlakuan (A2) pemberian 
reward dengan model tabungan kepingan berdasarkan dari hasil analisisuji peringkat bertanda Wilcoxon.

Hal ini sesuai dengan hasil observasi yang dilakukan selama penelitian bahwa ada perbedaan rerata skor kepatuhan antara yang sebelum diberi perlakuan dan saat diberi perlakuan itu terjadi peningkatan rerata skor kepatuhan dari kategori sedang menjadi kategori tinggi.

Penelitian ini memiliki beberapa kelemahan yaitu metode penelitian yang dilakukan, pengambilan subjek penelitian tidak dilakukan secara random, jumlah subjek yang sangat terbatas sehingga hasilnya belum dapat dijadikan sebagai generalisasi secara umum di semua tempat dan terhadap setiap anak

\section{SIMPULAN}

Berdasarkan hasil penelitian yang diperoleh, dapat disimpulkan bahwa pemberian reward dengan model tabungan kepingan memiliki pengaruh signifikan terhadap kepatuhan anak usia dini. Ada perbedaan tingkat kepatuhan anak usia dini antara sebelum (A1) dan ketika (B) diberi reward dengan model tabungan kepingan, tingkat kepatuhan sebelum (A1) diberi reward dengan model tabungan kepingan lebih rendah daripada ketika (B) diberi reward dengan model tabungan kepingan.

Tidak ada perbedaan tingkat kepatuhan anak usia dini antara ketika (B) diberi reward dengan model tabungan kepingan dengan sesudah (A2) diberi reward dengan model tabungan kepingan. Selain itu, ada perbedaan tingkat kepatuhan anak usia dini antara sebelum (A1) dan sesudah (A2) diberi reward dengan model tabungan kepingan, tingkat kepatuhan sebelum (A1) diberi reward dengan model tabungan kepingan lebih rendah daripada sesudah (A2) diberi reward dengan model tabungan kepingan.

Saran dari hasil penelitian menyatakan bahwa ada pengaruh reward dengan model tabungan kepingan terhadap kepatuhan anak, diharapkan hasil penelitian ini dapat memberikan informasi tentang pentingnya strategi pemberian reward dengan model tabungan kepingan untuk membentuk dan meningkatkan kepatuhan anak sehingga guru dapat menerapkan pemberian reward untuk memperoleh kepatuhan siswa di sekolah.

Saran bagi peneliti selanjutnya yang tertarik dengan topik yang serupa diharapkan lebih mengembangkan dan menyempurnakan penelitian ini dengan memperbaiki metode penelitian yang dilakukan yaitu dengan pengambilan subjek penelitian dilakukan secara random, memastikan tentang efek pemberian reward dengan model tabungan kepingan dalam jangka waktu panjang yang mempunyai kemungkinan bahwa perilaku yang diberi penguatan akan menghilang ketika subjek sudah terbiasa dengan reward yang disediakan.

\section{DAFTAR PUSTAKA}

Budistyani, G. A. 2005, Pengaruh Reward dan System Kompetisi terhadap Prestasi Pemanah Indonesia, Anima, Vol 21. no 1. 53-65.

Hurlock, E. B. 1991.Perkembangan Anak: Suatu Pendekatan Sepanjang Rentang Kehidupan. Edisi kelima. Penerjemah : 
Istidayanti \& Soedjarwo. Jakarta : Erlangga.

Minza, W. M. 2001. Efektifitas Pelatihan Taktik Mempengaruhi Secara Rasional Terhadap Kepatuhan Anak. Psikologika, no 11, tahun VI. 15-26.

Myers. A, 2002. Experimental Psychology: Fifth edition. America: Wodsworths.

Nasrullah dan Nashori. 2004. Hubungan antara Persepsi Santri Terhadap Barokah Kiai Dengan Kepatuhan. UII : Publikasi Ilmiah.

Soekadji, S. 1983. Modifikasi Perilaku Penerapan Sehari-hari dan Penerapan Propesional. Jakarta : Liberty. 